\title{
Comparison of bioassays using the anostracan crustaceans Artemia salina and Thamnocephalus platyurus for plant extract toxicity screening
}

\author{
Pablo Mayorga, ,1 Karen R. Pérez, ${ }^{2}$ Sully M. Cruz, ${ }^{2}$ Armando Cáceres ${ }^{2}$
}

\begin{abstract}
${ }^{1}$ Servicios y Productos Ambientales, 20 Avenida A 3-35 apt. F zona 15, 01015 Ciudad de Guatemala, Guatemala, ${ }^{2}$ Departamento de Citohistología, Facultad de Ciencias Químicas y Farmacia, Universidad de San Carlos de Guatemala. Ciudad Universitaria, Edificio T-11, 01012 Ciudad de Guatemala, Guatemala.
\end{abstract}

\begin{abstract}
RESUMO: "Comparação de bioensaios com os crustáceos Artemia salina e Thamnocephalus platyurus para abordagem de extratos de plantas com toxicidade". Três bioensaios de letalidade com o crustáceo de água salgada Artemia salina Leach, Artemiidae, (teste convencional em microplaca de 96 poós Artoxkit microbiotest M) e o crustáceo de água doce Thamnocephalus platyurus Packard, Thamnocephalidae (Thamnotoxkit microbiotest $\mathrm{F}$ ), foram comparados utilizando extratos de dez espécies de plantas da Guatemala. Foi previamente observado que cinco delas possuem atividade anti-Artemia: Solanum americanum Mill., Solanaceae, Gliricidia sepium (Jacq.) Kunth ex Walp., Fabaceae, Neurolaena lobata (L.) Cass., Asteraceae, Petiveria alliacea L., Phytolaccaceae e Ocimum campechianum Mill., Lamiaceae. As outras cinco espécies, Curatella americana L., Dilleniaceae, Prunus barbata Koehne, Rosaceae, Quercus crispifolia Trel., Fagaceae, Rhizophora mangle L., Rhizophoraceae e Smilax domingensis Willd., Smilacaceae, não. Todas as plantas sem atividade anti-Artemia não tiveram nenhum efeito letal em ambos os ensaios com A. salina. Para as plantas com atividade anti-Artemia o M Artoxkit não foi sensível a G. sepium e teste convencional de Artemia não foi sensível a S. americanum, G. sepium e N. lobata. Todos os extratos vegetais, exceto o de C. americana, apresentaram um efeito letal sobre T. platyurus e a concentração letal média (CL50) para este organismo em todos os casos foram substancialmente inferiores aos da espécie de teste de água salgada. Este estudo revelou que T. platyurus é teste promissor para uma investigação aprofundada na seleção de extratos de plantas com potenciais propriedades medicinais.
\end{abstract}

Unitermos: Plantas medicinais, toxicidade, Artemia salina, Thamnocephalus platyurus, Artoxkit M, Thamnotoxkit F.

\begin{abstract}
Three lethality bioassays, using the salt-water crustacean Artemia salina Leach, Artemiidae, (conventional 96 microwell plate test and the Artoxkit M microbiotest) and the freshwater crustacean Thamnocephalus platyurus Packard, Thamnocephalidae, (Thamnotoxkit F microbiotest), were compared using extracts of ten Guatemalan plant species. It was previously observed that five of them have anti-Artemia activity. These were: Solanum americanum Mill., Solanaceae, Gliricidia sepium (Jacq.) Kunth ex Walp., Fabaceae, Neurolaena lobata (L.) Cass., Asteraceae, Petiveria alliacea L., Phytolaccaceae, and Ocimum campechianum Mill., Lamiaceae. The five others: Curatella americana L., Dilleniaceae, Prunus barbata Koehne, Rosaceae, Quercus crispifolia Trel., Fagaceae, Rhizophora mangle L., Rhizophoraceae, and Smilax domingensis Willd., Smilacaceae, do not. All plants without anti-Artemia activity had no lethal effects in both assays with A. salina. For the plants with anti-Artemia activity the Artoxkit $\mathrm{M}$ was not sensitive to G. sepium and the conventional Artemia test was not sensitive to $S$. americanum, $G$. sepium and $N$. lobata. All the plant extracts, except for that of C. americana, had lethal effects on T. platyurus and the lethal median concentration (LC50) levels for this organism were in all cases substantially lower than those of the salt-water test species. This study revealed that T. platyurus is a promising test species worth further in depth investigation for toxicity screening of plant extracts with potential medicinal properties.
\end{abstract}

Keywords: Medicinal plants extracts, toxicity screening, Artemia salina, Thamnocephalus platyurus, Artoxkit M, Thamnotoxkit F. 


\section{INTRODUCTION}

The brine shrimp, Artemia salina Leach, Anostraca: Artemiidae, (Figure 1), has been used for several decades as a test organism (Michael et al., 1956) in natural products research (Meyer et al., 1982) and to assess the effect of chemicals in aquatic environments (Persoone \& Wells, 1987). The Artemia assay is used routinely in laboratories around the world for prescreening of plant extracts with potential medicinal properties (e.g., antimicrobial or antiparasitic), for bioguided fractionation of bioactive constituents of plant extracts and for cytotoxic effects detection (Trotter et al., 1983; Anderson et al., 1991; Beloz, 1992; Solis et al., 1993; Sam, 1993; Zani et al., 1995; Adoum et al., 1997; Awachie \& Ugwu, 1997; Chávez et al., 1997; Cáceres et al., 1998; Moshi et al., 2004; Oliva et al., 2007).

The major reason why this salt-water anostracan crustacean is used widely for toxicity testing of plant extracts is due to the commercial availability of dormant eggs (cysts), which are harvested in huge amounts in salt lakes and pans. The larvae hatched from the cysts are used worldwide in aquaculture and in aquariology as live food for juvenile fish. Dormant brine shrimp eggs remain viable for many years and are therefore a suitable biological source for rapid, simple and inexpensive bioassays. A drawback of this bioassay, however, is that the saline medium decreases the solubility and bioavailability of some substances, thus limiting the detection of possible bioactive plant constituents.

In recent years, the controlled production of dormant stages of a number of aquatic test organisms has been achieved and stock culture and maintenancefree microbiotests have been developed (see the Cyst-based Toxicity Tests series of publications in www.microbiotests.be). These assays are available commercially as Toxkits (Persoone, 1991). One of these microbiotests, the Thamnotoxkit $\mathrm{F}$ with the fairy shrimp, Thamnocephalus platyurus Packard, Anostraca: Thamnocephalidae, (Figure 2), is particularly interesting for toxicity testing and screening of potential medicinal plants. T. platyurus is a freshwater relative of the brine shrimp and is very sensitive to a number of chemicals and environmental pollutants. A variety of research papers on environmental toxicity assessment using this organism have already been published, several of which are listed on the website www.microbiotests.be.

In the present study we compared the response of three bioassays to extracts of ten Guatemalan plant species used in traditional medicine: the Artemia test normally used for prescreening and toxicity testing of plant extracts (Solis et al., 1993; Cáceres et al., 1998), the Artoxkit $\mathrm{M}$ and the Thamnotoxkit $\mathrm{F}$ microbiotests. To our knowledge, this is the first attempt to compare the effects of plant extracts on $A$. salina with those on its freshwater relative T. platyurus.

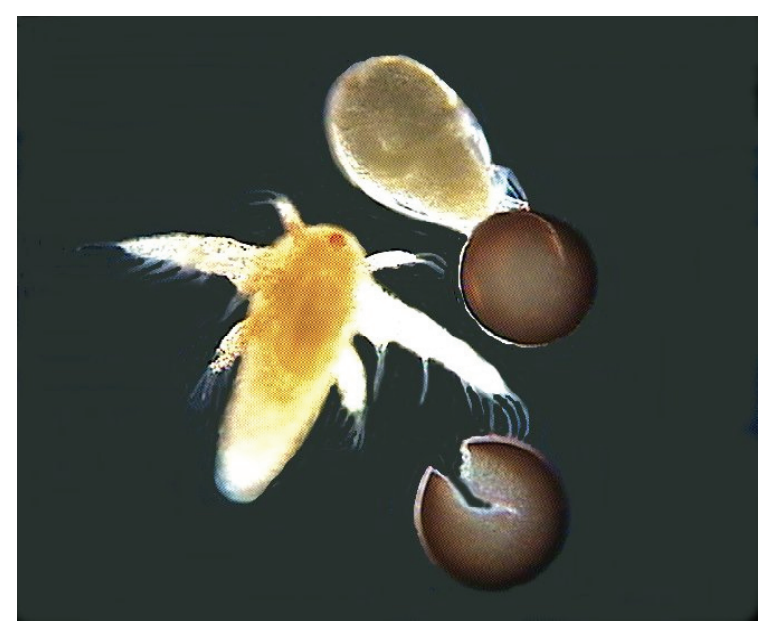

Figure 1. Recently hatched nauplius of A. salina, about $300 \mu \mathrm{m}$ long (photograph courtesy of Microbiotests, Inc.).

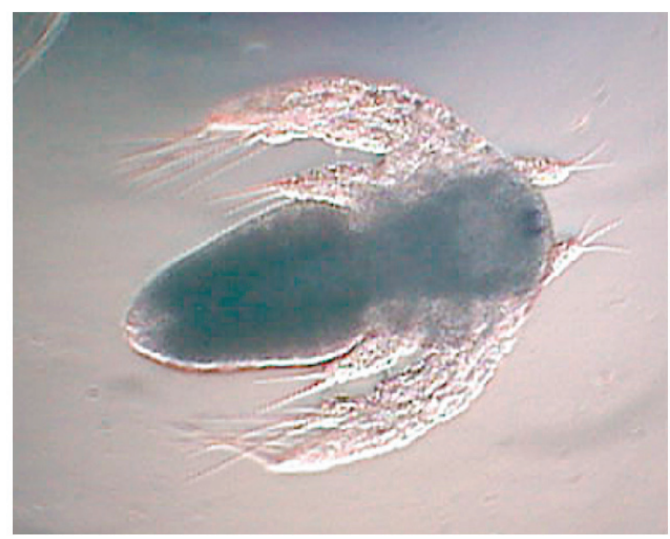

Figure 2. Instar I nauplius of T. platyurus (around $300 \mu \mathrm{m}$ long) (photograph courtesy of Microbiotests, Inc.).

\section{MATERIAL AND METHODS}

\section{Plant material and extracts}

Plants were collected in several Guatemalan locations. The specimens were authenticated by Ana María Ortiz (C.F.E.H. Herbarium), Juan José Castillo (Faculty of Agronomy, San Carlos University of Guatemala), Elfriede Pöll (UVAL Hebarium) and Mario Véliz (BIGU Herbarium). The specimens are stored in Farmaya's Ethnobotanical Herbarium (C.F.E.H), in Guatemala City, with the voucher numbers indicated in Tables 1 and 2 .

Plant material was shade-dried and extracted with $95 \%$ ethanol and concentrated to dryness by rotary evaporator. The essential oil of Ocimum campechianum Mill., Lamiaceae., was obtained by Neocleavenger hydrodistillation (BHMA, 1996). All material assayed (from now on referred to as extracts) was provided by the DepartmentofCytohistology,FacultyofChemicalSciences and Pharmacy, San Carlos University of Guatemala.

The plant species selected for the present study are used in Guatemala for medicinal purposes and their activities against $A$. salina have been previously 
Table 1. Guatemalan plant species used, reported to have anti-Artemia activity.

\begin{tabular}{llll}
\hline \multicolumn{1}{c}{ Species (part used) } & \multicolumn{1}{c}{ Reference } & Collection site & $\begin{array}{c}\text { Herbarium and voucher } \\
\text { number }\end{array}$ \\
\hline Solanum americanum Mill., Solanaceae (leaf) & Cáceres et al. (1998) & Samayac & $\begin{array}{l}\text { FARMAYA’s Ethnobotanical } \\
\text { Herbarium (C.F.E.H), 401 }\end{array}$ \\
Gliricidia sepium (Jacq.) Kunth., Fabaceae (bark) & Berger et al.(1998) & Samayac & C.F.E.H, 339 \\
$\begin{array}{l}\text { Neurolaena lobata } \text { R.Br., Asteraceae (leaf) } \\
\text { Petiveria alliacea } \text { L., Phytolaccaceae (root) }\end{array}$ & Berger et al.(1998) & Samayac & C.F.E.H, 160 \\
$\begin{array}{l}\text { Ocimum campechianum Mill., Lamiaceae (leaf, essential } \\
\text { oil) }\end{array}$ & Cruz (2001) & Samayac & C.F.E.H, 1049 \\
\hline
\end{tabular}

Table 2. Guatemalan plant species used, reported to be inactive against $A$. salina.

\begin{tabular}{|c|c|c|c|}
\hline Species (part used) & Reference & Collection site & $\begin{array}{c}\text { Herbarium and voucher } \\
\text { number }\end{array}$ \\
\hline Curatella americana L., Dilleniaceae (leaf) & Cáceres et al. (2001) & $\begin{array}{l}\text { Biosphere Reserve } \\
\text { Sierra de las Minas } \\
\text { (RBSM) }\end{array}$ & C.F.E.H., 1130 \\
\hline Prunus barbata Koehne, Rosaceae (leaf) & Cáceres et al. (2001) & RBSM & C.F.E.H, 755 \\
\hline Quercus crispifolia Trel., Fagaceae (leaf) & Cáceres et al. (2001) & RBSM & C.F.E.H, 754 \\
\hline Rhizophora mangle L., Rhizophoraceae (bark) & $\begin{array}{l}\text { Previously tested as } \\
\text { negative at our laboratory }\end{array}$ & Chiquimulilla & C.F.E.H, 323 \\
\hline Smilax domingensis Willd., Smilacaceae (rhizome) & Cáceres et al. (1998) & Samayac & C.F.E.H, 662 \\
\hline
\end{tabular}

determined by this Department. The 5 species found to have anti-Artemia activity are listed in Table 1. Cáceres (1999) describes botanical aspects, habitat, history, agriculture, medicinal uses, other popular uses, pharmacology, chemical composition, pharmacognosy, toxicology and therapeutic indications of these five plants. The other five species reported to be inactive against A. salina are listed in Table 2. Some of their medicinal uses are mentioned in the respective references.

Twenty $\mathrm{mg}$ of each extract concentrate were dissolved in $10 \mathrm{~mL}$ of the standard seawater or freshwater medium for $A$. salina or $T$. platyurus respectively. In the case of $O$. campechianum, $2 \mathrm{mg}$ of the essential oil were dissolved in $40 \mu \mathrm{L}$ dimethyl sulfoxide (DMSO) and $1.9 \mathrm{~mL}$ medium. DMSO is not toxic to any of the test organisms in the concentration used.

\section{Conventional microwell Artemia test}

The brine shrimp cysts of $A$. salina for the conventional Artemia test (Artemia test) were bought in a pet fish shop in Guatemala City. The bioassay with $A$. salina was originally described by Michael et al. (1956). The procedure was adapted to natural product research by Meyer et al. (1982), and the conventional microwell bioassay methodology used in this investigation followed the method described in Solis et al. (1993) and Cáceres et al. (1998).

\section{Artoxkit M}

The Artoxkit M kits used were obtained from Microbiotests, Inc., Mariakerke-Gent, Belgium. This microbiotest was developed and standardized in the Laboratory for Biological Research on Aquatic Pollution at the University of Ghent in Belgium (Vanhaecke \& Persoone, 1981, 1984; Van Steertegem \& Persoone, 1993).

The chemical compounds methodology indicated in the Standard Operational Procedure (SOP) of the Artoxkit M was followed (Artoxkit M, 2003).

The Artoxkit $M$ microbiotest differs from the Artemia test on several points, which are mentioned below. The kit contains all the materials necessary to perform up to six tests, including Artemia cysts of a standard reference stock. A 24-microwell plate with $1 \mathrm{~mL}$ of sample per well is used, instead of a 96-microwell plate with $200 \mu \mathrm{L}$ per well. The hatching of the cysts is carried out by exposure to a fluorescent light source of 3000-4000 lux for $30 \mathrm{~h}$ at $25^{\circ} \mathrm{C}$ and newly hatched nauplii are used since they molt rapidly to older stages. The nauplii are transferred from the hatching medium to a rinsing well containing the test solution (this avoids dilution from transferring hatching medium to the test sample). Then, ten nauplii are exposed in triplicate to each concentration of the test sample in the remaining wells and the dead larvae are counted at the end of the test. Methanol killing is not necessary since the exact number of organisms is known. The incubation is carried out in the dark at 25 ${ }^{\circ} \mathrm{C}$ with results read at $24 \mathrm{~h}$ and, if no effect has been observed, at $48 \mathrm{~h}$. A range finding test is performed 
with 1:10 dilutions of the stock solution, followed by the preparation of a logarithmic set of five dilutions between the dilutions showing 0 and $100 \%$ mortality in the range finding test to determine a precise median lethal concentration (LC50) and a 95\% confidence interval.

\section{Thamnotoxkit F}

The Thamnotoxkit $\mathrm{F}$ kits used were obtained from Microbiotests, Inc., Mariakerke-Gent, Belgium.

Freshly hatched larvae of the freshwater fairy shrimp T. platyurus are used as test organisms in the Thamnotoxkit $\mathrm{F}$ microbiotest. The test is performed according to the chemical compounds procedure indicated in the SOP of this assay (Thamnotoxkit, 2003). The procedure is very similar to the SOP of the Artoxkit M, except that standard freshwater is used and the hatching takes place under constant exposure to a fluorescent light source (3000-4000 lux), for a 20-22 h period.

In all bioassays used here, a negative control was carried out exposing the test organisms to standard dilution water (fresh or sea water). If mortality exceeded $10 \%$ the assay should be repeated. With the Artoxkit M and Thamnotoxkit F, a test with the reference toxicant potassium dichromate was carried out for quality assurance and the LC50's obtained were within the range indicated in the specification sheets provided with each kit.

\section{LC50 estimation}

A computerized program was used to estimate the LC50's and the 95\% confidence intervals (US EPA, 1985). Extracts with LC50's higher than $1000 \mu \mathrm{g} / \mathrm{mL}$ were considered not to have biological activity (Berger et al., 1998).

\section{RESULTS AND DISCUSSION}

The LC50's and 95\% confidence intervals for the three bioassays on the extracts of the ten plants are presented in Table 3.

For the Artemia tests, all the extracts known to have no anti-Artemia activity did not induce lethal effects either in the Artoxkit M or in the Artemia test. The Artoxkit M was not sensitive (even after $48 \mathrm{~h}$ of exposure) to G. sepium while the Artemia test was not sensitive (after $24 \mathrm{~h}$ ) to $S$. americanum, G. sepium and $N$. lobata. Prolongation of the exposure time to $48 \mathrm{~h}$ (in the Artoxkit M) instead of $24 \mathrm{~h}$ (as in the Artemia test) resulted in detectable LC50 values for S. americanum and N. lobata.

All extracts induced lethal effects on the Thamnotoxkit $\mathrm{F}$ crustaceans except for $C$. americana. LC50's were in all cases substantially lower for the Thamnotoxkit F assays than for the Artemia tests, except for $O$. campechianum where the difference, between the Thamnotoxkit $\mathrm{F}$ and the Artoxkit $\mathrm{M}$ data, was slight.

Although three of the five extracts known to have activity against $A$. salina had no effect on the Artemia test, four did on the Artoxkit M. We cannot explain why G. sepium had no activity in either of the A. salina tests. This may possibly be due to natural variations in the concentration of bioactive components in the original plant material, or perhaps due to storage conditions. As an example of the first possibility, in Cáceres et al. (1998) N. lobata showed no activity against $A$. salina but was active

Table 3. LC50's and 95\% confidence intervals (CI) of plant extracts, tested with the Artemia test, Artoxkit M and Thamnotoxkit F.

\begin{tabular}{|c|c|c|c|}
\hline \multicolumn{4}{|c|}{$\mathrm{LC} 50$ in $\mu \mathrm{g} / \mathrm{mL}$ (and $95 \% \mathrm{CI}$ ) } \\
\hline Plant species & Artemia test $24 \mathrm{~h}$ & Artoxkit M $24 \mathrm{~h}$ [and $48 \mathrm{~h}^{\mathrm{a}}$ ] & Thamnotoxkit F 24 h \\
\hline \multicolumn{4}{|c|}{ With previously demonstrated anti-Artemia activity } \\
\hline S. americanum & $>1000$ & $\begin{array}{c}>1000 \\
{[565(380-845)]}\end{array}$ & $219(173-281)$ \\
\hline O. campechianum & $328(260-393)$ & $114(86-166)$ & $95(68-132)$ \\
\hline P. alliacea & $228(157-271)$ & $481(367-669)$ & $12(9-14)$ \\
\hline G. sepium & $>1000$ & $>1000$ & $492(399-587)$ \\
\hline N. lobata & $>1000$ & $\begin{array}{c}>1000 \\
{[902(794-1032)]}\end{array}$ & $251(225-274)$ \\
\hline \multicolumn{4}{|c|}{ Without previously demonstrated anti-Artemia activity } \\
\hline C. americana & $>1000$ & $>1000$ & $>1000$ \\
\hline R. mangle & $>1000$ & $>1000$ & $84(63-110)$ \\
\hline P. barbata & $>1000$ & $>1000$ & $405(344-486)$ \\
\hline Q. crispifolia & $>1000$ & $>1000$ & $201(177-226)$ \\
\hline S. domingensis & $>1000$ & $>1000$ & $70(52-92)$ \\
\hline
\end{tabular}

${ }^{\text {aThis }}$ is analogous to the Daphnia magna acute assay (ISO 6341), for which the exposure period is also $24 \mathrm{~h}$, but it can be (and has been) prolonged to $48 \mathrm{~h}$. This was done only in cases where no toxic response was observed after $24 \mathrm{~h}$. If no other value is indicated, the LC50 was still $>1000 \mu \mathrm{g} / \mathrm{mL}$ after $48 \mathrm{~h}$. 
against several pathogens. Berger et al. (1998) reported that this plant had both anti-Artemia (LC50=495.1 $\mu \mathrm{g} /$ $\mathrm{mL} \pm 42.1)$ and anti-trypanosome activity. However, the extracts without previously reported anti-Artemia activity showed no anti-Artemia activity in the present study.

The results of the present study clearly show that the bioassay with $T$. platyurus detects bioactive components that $A$. salina may not. In fact, nine of the plant species used here, including three of those previously reported not to have anti-Artemia activity (R. mangle, $Q$. crispifolia and $S$. domingensis) have proven to have biocide properties against one or more human pathogens (bacteria, fungi, trypanosomes and leishmanias) and mosquito larvae (Cáceres et al., 1991; Cáceres et al., 1998; Berger et al., 1998; Cáceres, 1999; Cáceres et al., 2001). C. americana, which did not have lethal effects against either crustacean, showed antibacterial activity (Cáceres et al., 2001). Although $P$. barbata had activity against $T$. platyurus, no antipathogen activity has been reported (Cáceres et al., 2001). Based on these results, however, it could be worthwhile to determine if it causes other pharmacological effects (e.g., anti-inflammatory and antiaterogenic effects, hypoglycemia, analgesia, diuresis, hepatoprotection, and effects on the central nervous system). Morales et al. (2001) and Morales Cifuentes et al. (2001) have reported effects of G. sepium, N. lobata and P. alliaceae extracts on the central nervous system of Swiss albino mice. Bioguided fractionation of plant extracts using $T$. platyurus could be of interest in future studies. However, "Very often the chemical complexity of the crude or partially purified extract seems to be essential for the bioavailability of the active constituents... It is often found that, when individual constituents are isolated from the plant extract there is loss of specific bio-activity." (Bhattacharya, 2009). Therefore, when initial bioactivity screening is done, the use of complex whole plant extracts is more suitable and significant than studying fractions.

The toxicity of pharmaceuticals has been determined with many test organisms, including T. platyurus and A. salina. Nałęcz-Jawecki \& Persoone (2006) present toxicity information for several pharmaceuticals using T. platyurus. From the data published by these authors and those reported by Calleja et al. (1994) on assays with $A$. salina, it also appears that $T$. platyurus is more sensitive to paracetamol, caffeine and theophylline.

Finally, it is worth mentioning not only that $A$. salina is still regularly used for cyanotoxin detection and screening of biologically active substances from blue green algae (e.g., Mian et al., 2003), but that Törökné (1999) reported better results using T. platyurus for the same purpose. Marsalek \& Blaha (2003) reported that, out of nineteen bioassay species, T. platyurus was the most sensitive for cyanotoxin detection. Our findings therefore show that T. platyurus is more sensitive than A. salina for detecting toxic effects of plant extracts. Because of this, we suggest that the acute bioassay with the freshwater fairy shrimp is worth pursuing as an interesting substitute for the brine shrimp test in bioactive natural products research. A second study is currently being carried out to test a larger set of plant extract samples in order to confirm the present trend.

\section{ACKNOWLEDGMENTS}

The authors thank: Microbiotests, Inc., for donating biological material of the Artoxkit $\mathrm{M}$ and Thamnotoxkit F; the Department of Cytohistology, Faculty of Chemical Sciences and Pharmacy, for providing plant extracts (Gerber Solís, Ingeborg Berger and Claudia Morales), part of the literature cited (Isabel Gaitán), materials and laboratory facilities for performing the Artemia test; SEPRA for providing facilities and additional materials to perform the Toxkit tests; and Margaret Dix for manuscript revision.

\section{REFERENCES}

Adoum OA, Dabo NT, Fatope MO 1997. Bioactivities of some savanna plants in the brine shrimp lethality test and in vitro antimicrobial assay. Int J Pharmacol 35: 334-337.

Anderson JE, Goetz CC, McLaughlin JL, Sufness M 1991. A blind comparison of simple bench-top bioassays and human tumor cell cytotoxicities as antitumor prescreens. Phytochem Analysis 2: 107-111.

Artoxkit M 2003. Artemia toxicity screening test for estuarine and marine waters. Standard Operational Procedure. Mariakerke-Gent: Microbiotests.

Awachie PIA, Ugwu FO 1997. Preliminary investigation of the antimicrobialandbrineshrimplethality properties of some Nigerian medicinal plants. Int J Pharmacol 35: 338-343.

Bhattacharya S 2009. Phytosomes: The new technology for enhancement of bioavailability of botanicals and nutraceuticals. Int $J$ Health Res 2: 225-232.

Beloz A 1992. Brine shrimp bioassay screening of two medicinal plants used by the Warao: Solanum straminifolium and Virola surinamensis. J Ethnopharmacol 37: 225-227.

Berger I, Barrientos AC, Cáceres A, Hernández M, Rastrell L, Passreiter CM, Kubelka W 1998. Plants used in Guatemala for the treatment of protozoal infections. II. Activity of extracts and fractions of five Guatemalan plants against Trypanosoma cruzi. J Ethnopharmacol 62: 107-115.

BHMA (British herbal pharmacopoeia) 1996. 4.ed. Exeter: British Herbal Medicine Association. Cáceres A, López BR, Girón MA, Logemann H 1991. Actividad antimicótica de plantas usadas en Guatemala para el tratamiento de dermatofitosis. Rev Mex Mic 7: 21-38.

Cáceres A, López B, González S, Berger I, Tada I, Mak J 1998. Plants used in Guatemala for the treatment of protozoal infections. I. Screening of activity to bacteria, fungi 
and American trypanosomes of 13 native plants. $J$ Ethnopharmacol 62: 195-202.

Cáceres A 1999. Plantas de uso medicinal en Guatemala. Guatemala: Editorial Universitaria.

Cáceres A, Barrios M, Morales C, Orellana R, Vásquez A, Flores M, Tally W, Cruz S, Arana S, Paz M 2001. Actividad biocida de plantas detectadas por etnobotánica y bioprospección en la Reserva de Biósfera Sierra de las Minas. Ciencia \& Tecnología 6: 23-47.

Calleja MC, Persoone G, Geladi P 1994. Comparative acute toxicity of the first 50 Multicentre Evaluation of in vitro cytotocity chemicals to aquatic non-vertebrates. Arch Environ Con Tox 26: 69-78.

Chávez PI, Sánchez LA, González FA, Rodríguez JL, Axelrod F 1997. Cytotoxicity correlations of Puerto Rican plants using a simplified brine shrimp lethality screening procedure. Int J Pharmacol 35: 222-226.

Cruz SM 2001. Fraccionamiento bioguiado y tamizaje fitoquímico del extracto etanólico con actividad antiArtemia de Ocimum micranthum Willd (albahaca de monte). Guatemala, 56 p. Tesis de Licenciatura, Escuela de Química Farmacéutica, Universidad de San Carlos de Guatemala.

Marsalek B, Blaha L 2003. Comparison of 19 bioassays for cyanotoxin detection. 11th International Symposium on Toxicity Assessment. Vilnius, Lithuania.

Meyer BN, Ferrigni NR, Putnam JI, Jacobsen LB, Nichols DE, McLaughlin JL 1982. Brine shrimp: A convenient general bioassay for active plant constituents. Planta Med 45: 31-34.

Mian P, Heilmann J, Bürgi H-R, Sticher O 2003. Biological screening of terrestrial and freshwater cyanobacteria for antimicrobial activity, brine shrimp lethality, and cytotoxicity. Pharm Biol 41: 243-247.

Michael AS, Thompson CG, Abramovitz M 1956. Artemia salina as a test organism for bioassay. Science 123 : 464.

Morales C, Gómez-Serranillos MP, Iglesias I, Villar AM, Cáceres A 2001. Preliminary screening of five ethnomedicinal plants of Guatemala. Il Farmaco 56: 523-526.

Morales Cifuentes C, Gómez-Serranillos MP, Iglesias I, Villar del Fresno AM, Morales C, Paredes ME, Cáceres A 2001. Neuropharmacological profile of ethnomedicinal plants of Guatemala. J Ethnopharmacol 76: 223-228.

Moshi MJ, Cosam JC, Mbwambo ZH, Kapingu M, Nkunya MHH 2004. Testing beyond ethnomedical claims: brine shrimp lethality of some Tanzanian plants. Pharm Biol 42: 547-551.

Nałęcz-Jawecki G, Persoone G 2006. Toxicity of selected pharmaceuticals to the anostracan crustacean Thamnocephalus platyurus. Comparison of sublethal and lethal effect levels with the $1 \mathrm{~h}$ Rapidtoxkit and the 24h Thamnotoxkit microbiotests. Environ Sci Pollut $R$ 13: $22-27$

Oliva M de las M, Gallucci N, Zygadlo JA, Demo MS 2007. Cytotoxic activity of Argentinean essential oils on
Artemia salina. Pharm Biol 45: 259-262.

Persoone G 1991. Cyst-based toxicity tests: I. A promising new tool for rapid and cost effective toxicity screening of chemicals and effluents. Z Angew Zool 78: 235-241.

Persoone G, Wells P 1987. Artemia in aquatic toxicology-A review. In: Sorgeloos P, Bengtson DA, Decleir W, Jaspers E (eds.). Artemia Research and its Applications. Morphology, Genetics, Strain Characterisation, Toxicology. Wetteren: Universa Press, p. 259-275.

Sam TW 1993. Toxicity testing using the brine shrimp: Artemia salina. In: Colegate SM, Moluneux RJ (eds.). Bioactive natural products. Detection, isolation and structural determination. Boca Raton: CRC Press, p. 441-456.

Solis PN, Wright CW, Anderson MM, Gupta MP, Phillipson JD 1993. A microwell cytotoxicity assay using Artemia salina (brine shrimp). Planta Med 59: 250-252.

Thamnotoxkit F 2003. Crustacean toxicity screening test for freshwater. Standard Operational Procedure. Mariakerke-Gent: Microbiotests.

Törökne AK 1999. A new culture-free microbiotest for routine detection of cyanobacterial toxins. Environ Toxicol 14: 466-472.

Trotter II RT, Logan MH, Rocha JM, Boneta JL 1983. Ethnography and bioassay: Combined methods for a preliminary screen of home remedies for potential pharmacological activity. J Ethnopharmacol 8: 113119.

US EPA 1985. Methods for measuring the acute toxicity of effluents to freshwater and marine organisms. Toxdat. Multimethod program (binomial, moving average and probit). 3.ed. Cincinnati: Environmental Monitoring and Support Laboratory, U. S. Environmental Protection Agency, EPA/600/4-85/013.

Vanhaecke P, Persoone G 1981. Report on an intercalibration exercise on a short-term standard toxicity test with Artemia nauplii (ARC-test). In: Leclerc H, Dive D (eds.). Les tests de toxicité aigue en milieu aquatique, Les colloques de l'INSERM. Paris: Ministère de la Santé, Institut National de la Santé et de la Recherche Médicale, p. 359-376.

Vanhaecke P, Persoone G 1984. The ARC-test: a standardized short-term routine toxicity test with Artemia nauplii. Methodology and evaluation. In: Persoone G, Jaspers E, Claus C (eds.). Ecotoxicological testing for the marine environment. Experience papers: Tests with specific groups of organisms; Tests with specific chemicals; Tests using a specific technology; Tests studying specific effects; Case study. Ghent: State University of Ghent and Institute of Marine and Scientific Research, p. 143158.

Van Steertegem M, Persoone G 1993. Cyst-based toxicity tests: V. Development and critical evaluation of standardized toxicity tests with the brine shrimp (Anostraca, Crustacea). In: Soares AMVM, Calow P (eds.). Progress in standardization of aquatic toxicity tests. NewYork: Lewis Publishers, p. 81-97. 
Zani CL, Chaves PPG, Queiroz R, de Oliveira AB, Cardoso JE, Anjos MG, Grandi TSM 1995. Brine shrimp lethality assay as a prescreening system for anti-Trypanosoma cruzi activity. Phytomedicine 2: 47-50. 